\title{
Does microwaving or freezing reduce the losses of non-structural carbohydrates during plant sample processing?
}

\author{
Frida I. Piper ${ }^{1} \cdot$ Andrea Reyes $^{1}$
}

Received: 28 November 2019 / Accepted: 26 February 2020 / Published online: 27 March 2020

(C) INRAE and Springer-Verlag France SAS, part of Springer Nature 2020

\begin{abstract}
- Key message Non-structural carbohydrates (NSC) are the main form of carbon storage in broadleaved trees; precise NSC quantification is relevant to predict forest resilience. Sample microwaving before drying is considered to reduce NSC losses; however, evidence is scarce. We demonstrate that microwaving leaf and branch sapwood samples before drying did not significantly reduce NSC losses with respect to freezing or direct stove-drying.

- Context Non-structural carbohydrates (NSC) mediate tree survival, but precise determinations of NSC concentrations remain challenging. An unclear aspect is whether carbohydrate losses during sample processing can be reduced by different sample treatments. - Aims We postulated that due to higher metabolic rates, leaves should be more responsive to sample treatments than branch sapwood, and resource-acquisitive species should be more responsive to sample treatment than resource-conservative species.

- Methods In leaves and branch sapwood of six tree species, we compared the effects of three sample treatments on the concentrations of NSC, starch, and low-molecular weight sugars: sample microwaving before drying (microwave), sample freezing at $-20^{\circ} \mathrm{C}$ before drying (freezing), and only drying (stove).

- Results We found that across species and tissues, freezing led to significantly higher NSC and sugar concentrations than microwave and stove. This effect was, however, entirely driven by the leaves. Although the effect of sample treatments on NSC, starch, and sugar concentrations differed among species, resource-acquisitive species were not necessarily more affected by sample treatments than resource-conservative species.

- Conclusion Results suggest that either freezing or microwaving does not reduce carbohydrate losses in branch sapwood during sample handling and processing; however, freezing reduces leaf sugar and NSC losses when compared with microwave or direct stove-drying (194 words).
\end{abstract}

Keywords Functional traits $\cdot$ Starch hydrolysis $\cdot$ Microwave $\cdot$ Respiration $\cdot$ Starch $\cdot$ Sugars

\section{Introduction}

Most tree species, particularly angiosperms, store photoassimilates as non-structural carbohydrates (NSC) which can be

Handling Editor: Andrew Merchant

Contribution of the co-authors Conceptualization: F.I.P and A.R; Methodology: A.R.; Statistical analyses: F.I.P; Writing: F.I.P.

Frida I. Piper

fridapiper@gmail.com

Andrea Reyes

andrea.reyes.alvear@gmail.com

1 Centro de Investigación en Ecosistemas de la Patagonia (CIEP), Camino Baguales s/n, Coyhaique, Chile subsequently remobilized to support growth and respiration (Chapin et al. 1990). As such, NSC are fundamental for tree growth in seasonal climates, where carbon gain and carbon demand are not synchronic throughout the year (Martínez-Vilalta et al. 2016). Additionally, NSC mediate tree survival and hence forest resilience in response to disturbances like herbivory (Piper and Fajardo 2014; Piper et al. 2017) or fire (Canadell and LópezSoria 1998), and also in response to prolonged droughts (Galiano et al. 2011; Piper and Fajardo 2016; Adams et al. 2017), all of which are expected to become more severe and frequent under climate change. In spite of the enormous importance of NSC for plant ecology and the prediction of vegetation responses to climate change, its accurate determination is challenging (Quentin et al. 2015; Landhäusser et al. 2018; Pinkard 2018). 
A key step in NSC determination concerns the handling and processing of plant samples prior to NSC analysis. During the time elapsed from tissue sampling to chemical analyses (e.g., first processing, transportation) significant carbohydrate losses may occur, leading to underestimations in the NSC concentrations. Starch and sucrose hydrolysis and respiration are two main causes of NSC losses, and both processes are known to increase with temperature (Smith 1973; Labate and Leegood 1989; Steffen et al. 1989). Thus, hydrolysis and respiration may continue after tissue sampling and can actually increase when samples are directly (i.e., with no pretreatment) dried in a stove or if, for instance, samples are meanwhile stored in a room or left inside a car for several hours before transportation to the lab. Although freezedrying is generally acknowledged as the best method to preserve samples for NSC analyses, it is time-demanding and requires expensive equipment. More importantly, field studies often require long periods of sampling before sample transportation to lab facilities; hence, a simpler and affordable method to preserve plant samples during field campaigns is necessary. Apart from freeze-drying, two widely used techniques to preserve plant samples are microwaving shock and freezing at $-20{ }^{\circ} \mathrm{C}$ (Hendrix et al. 1994; Piispanen and Saranpää 2001). These two methods require simple equipment (a microwave and a refrigerator, respectively). Microwave shock denatures enzymes and hence stops hydrolysis and respiration (Popp et al. 1996; Quentin et al. 2015). Freezing at $20^{\circ} \mathrm{C}$, on the other hand, prevents hydrolysis and respiration due to partial enzymatic deactivation. However, during freezing and subsequent thawing, specific carbohydrates can be degraded due to thawing-induced hydrolysis (Hendrix and Peelen 1987). Additionally, freeze-thaw events may cause carbohydrate losses due to leakage (Steffen et al. 1989; Tao et al. 2015), suggesting that microwaving can better preserve plant samples than freezing. Frequently, no sample pretreatment is applied before NSC determinations (Klein et al. 2014; Wiley et al. 2016; Wyka et al. 2016). It remains unknown whether the values reported by these studies represent NSC concentrations significantly different regarding those potentially determined after sample pretreatments by microwave or freezing.

Using leaves, buds, and inner bark of two herbaceous and two tree species, microwaving was found to be as efficient as freeze-drying for sample preservation (Popp et al. 1996), and both significantly more efficient than directly drying. Likewise, microwaving was similarly efficient as freezedrying for spruce needles, and even more efficient for aspen leaves and twigs (Landhäusser et al. 2018). However, differences found by this study were minimal and inconsistent among NSC fractions (Landhäusser et al. 2018). For example, low-molecular weight sugar concentrations in spruce needles were unaffected by pretreatments (microwave or freeze-drying), and freeze-drying had no effect on NSC, starch, or sugar concentrations of aspen twigs (Landhäusser et al. 2018). A distinctive aspect of the previous studies is that they examined tissues with no or little lignification. Even the twigs of aspen were little lignified as inferred by their small diameters. Thus, the extent to which the hydrolysis of oligo and polysaccharides and the carbohydrate respiration causes substantial carbohydrate losses during sample processing, and whether these losses can be reduced by different sample treatments, remains unclear for woody tissues.

Woody tissues contain NSC in the parenchyma cells of the sapwood (Plavcova et al. 2016), which is generally less metabolically active per mass unit than inner bark or leaves (Butler and Landsberg 1981). Also, the respiration rate and the concentration per mass unit of hydrolases and respiratory enzymes are higher in leaves than in woody tissues. Thus, it can be expected that the effectiveness of pretreatments to reduce hydrolysis and respiration losses will depend on the organs, being less effective in woody than in foliar tissue. Similarly, sample pretreatment effectiveness could vary among plant functional groups. Fast-growing species are generally characterized by low wood density, high nutrient concentrations, and high respiratory rates, relative to slowgrowing and more resource-conservative species. Therefore, they are expected to be more responsive to sample pretreatment. Leaking losses associated with freeze-thaw events could also be lower in woody than in leaf tissue due to longer leaking pathway and higher membrane stability under freezing temperatures in the former (Sakai and Larcher 1987). In this study, we compare the efficacy of commonly used fieldbased methods of sample processing to reduce carbohydrate loss. Specifically, we quantified total NSC, starch, and sugar concentrations of branch sapwood and leaves in six temperate species of contrasting tissue density as affected by three sample treatments: microwaving shock before stove-drying, freezing at $-20{ }^{\circ} \mathrm{C}$ before stove-drying, and only stove-drying.

\section{Material and methods}

\subsection{Sampling}

Sample collection was performed in May 2017 within the Coyhaique National Reserve (45 $59^{\prime} \mathrm{S}$ and $71^{\circ} 52^{\prime} \mathrm{W}$, $650 \mathrm{~m}$ above sea level (a.s.1.)), Coyhaique Province, Patagonia (Chile). Here, the mean annual and growing season (October-March) precipitation are $921 \mathrm{~mm}$ and $347 \mathrm{~mm}$, respectively, and the mean annual and growing season temperatures are $8.0{ }^{\circ} \mathrm{C}$ and $11.2{ }^{\circ} \mathrm{C}$, respectively (Coyhaique National Reserve weather station, Dirección General de Aguas, 2002-15, $400 \mathrm{~m}$ a.s.1.). On the day of sampling, the temperature was c. $10^{\circ} \mathrm{C}$ and in the laboratory it was $18^{\circ} \mathrm{C}$. Six woody species were selected to represent a range of leaf and wood economies (Table 1). Thus, Berberis microphylla G. Forst., Embothrium coccineum J.R.Forst. \& G.Forst., and 
Table 1 Specific leaf area (SLA), wood density (WD), and nitrogen (N) and phosphorus (P) concentrations in branch sapwood and leaves of six woody species sampled for this study in Reserva Nacional Coyhaique, in May 2017. Species leaf habit is indicated in parentheses next to species name

\begin{tabular}{lrccccc}
\hline Sampled species & SLA $\left(\mathrm{cm}^{2} \mathrm{~g}^{-1}\right)$ & WD $\left(\mathrm{g} \mathrm{cm}^{-3}\right)$ & Leaf N (\%) & Leaf P $\left(\mathrm{mg} \mathrm{g}^{-1}\right)$ & Branch N (\%) & Branch P (mg g $)$ \\
\hline Berberis microphylla (E) & $65.27 \pm 0.16$ & $0.72 \pm 0.01$ & $1.23 \pm 0.08$ & $0.66 \pm 0.04$ & $0.51 \pm 0.02$ & $0.33 \pm 0.02$ \\
Embothrium coccineum (E) & $71.07 \pm 3.14$ & $0.61 \pm 0.01$ & $1.54 \pm 0.16$ & $0.59 \pm 0.08$ & $0.34 \pm 0.03$ & $0.13 \pm 0.01$ \\
Nothofagus dombeyi (E) & $65.24 \pm 3.05$ & $0.55 \pm 0.01$ & $1.53 \pm 0.04$ & $1.25 \pm 0.14$ & $0.39 \pm 0.03$ & $0.55 \pm 0.13$ \\
Nothofagus antarctica (D) & $107.19 \pm 6.06$ & $0.61 \pm 0.01$ & $1.67 \pm 0.07$ & $0.97 \pm 0.16$ & $0.59 \pm 0.07$ & $0.32 \pm 0.02$ \\
Nothofagus pumilio (D) & $168.72 \pm 8.95$ & $0.56 \pm 0.02$ & $1.73 \pm 0.15$ & $1.66 \pm 0.11$ & $0.38 \pm 0.06$ & $0.21 \pm 0.04$ \\
Ribes magellanicum (D) & $114.98 \pm 9.52$ & $0.63 \pm 0.02$ & $1.59 \pm 0.14$ & $2.45 \pm 0.81$ & $0.57 \pm 0.07$ & $2.07 \pm 1.25$ \\
\hline
\end{tabular}

$E$ evergreen, $D$ deciduous

Nothofagus dombeyi Blume are evergreen species, while Nothofagus antarctica Oerst., Nothofagus pumilio Krasser, and Ribes magellanicum Poir are winter deciduous species. Also, B. microphylla and R. magellanicum are shrubs, while the other species are trees.

Six individuals of similar size were selected per species. One terminal, $\sim 1 \mathrm{~m}$ long, fully expanded, sun-exposed branch was cut at breast height. From each of these branches, we collected sun-exposed leaves of the two last cohorts (current and previous growing season) and 4-year-old branch segments (with bark and phloem removed in the field with a knife) for NSC determination. Samples were immediately transported to the lab, where they were assigned to each of three treatments. The first treatment consisted of the application of a microwave shock ( 3 cycles $\times 30 \mathrm{~s}$ each at $700 \mathrm{~W}$ ) (Fancy 2000, Somela), followed by $72 \mathrm{~h}$ of drying in a forcedair stove at $70{ }^{\circ} \mathrm{C}$ (Memmert GmbH, Schwabach, Germany). For this, samples were separately placed into paper bags properly labeled, and turned around between microwave cycles. No more than five bags were placed in the microwave at a same time. In the second treatment, samples were put inside Ziploc bags, frozen at $-20{ }^{\circ} \mathrm{C}$ for 7 days, and then dried for $72 \mathrm{~h}$ at $70{ }^{\circ} \mathrm{C}$ in the forced-air stove. Finally, in the third treatment, samples were directly placed into the forced-air stove at $70{ }^{\circ} \mathrm{C}$ for $72 \mathrm{~h}$ (i.e., no pretreatment was applied). Samples from the three treatments were ground into a fine powder and stored in dry and cool conditions until chemical analyses were conducted.

\subsection{NSC determination}

NSC concentrations were determined as the sum of the three most abundant low-molecular weight soluble sugars (glucose, fructose, and sucrose) and starch. The NSC concentrations were analyzed following the procedure of Hoch et al. (2002) with some modifications. About $13 \mathrm{mg}$ of dried powder were extracted with $1.6 \mathrm{ml}$ of distilled water at $100{ }^{\circ} \mathrm{C}$ for $60 \mathrm{~min}$. An aliquot of the extract was used to determine low-molecular weight soluble sugars after enzymatic conversion (invertase and phosphoglucose isomerase from Saccharomyces cerevisiae, Sigma-Aldrich I4504 and P5381, respectively, St Louis, MO, USA) of sucrose and fructose to glucose. The concentration of free glucose was determined photometrically at $340 \mathrm{~nm}$ after the enzymatic conversion of glucose to gluconate-6-phosphate (Glucose Assay Reagent, G3293 Sigma-Aldrich) on a 96-well multiplate reader. Following the degradation of starch to glucose using a purified fungal amylase ("amiloglucosydase" from Aspergillus niger, SigmaAldrich 10115) at $45^{\circ} \mathrm{C}$ overnight, NSC was determined in a separate analysis. The starch concentration was calculated as NSC minus the sum of free sugars. Total low-molecular weight soluble sugars, starch, and NSC concentrations are presented as percent of dry matter (Piper and Reyes 2020).

\subsection{Data analyses}

The influence of species, plant tissue (branch sapwood, leaves) and sample treatment (microwave, freezing, stove), and the interactions among them, on NSC, starch, and sugar concentrations were analyzed with linear mixed-effects models, considering the individuals as the random factor. Starch concentrations were square-transformed before analysis to meet normality assumptions. When a fixed factor or the interaction among factors proved to have a significant effect on NSC, starch, or sugar concentrations, we conducted post hoc multiple comparisons (Tukey's procedure) among all combinations of factors. NSC and sugar concentrations were normally distributed, but starch concentrations were $\left(\log _{10} y+1\right)$ transformed before analyses, in order to achieve normality. All analyses were performed in JMP Version 14.0 (SAS Institute, Cary, NC, USA).

\section{Results}

NSC, starch, and sugar concentrations were significantly different among species and tissues (Table 2, Fig. 1). Across species and sample treatments, leaves had greater NSC, starch, and sugar concentrations than branch sapwood (i.e., significant effect of Tissue, Table 2, Fig. 1). However, there were interspecific differences in the proportion of NSC, 
Table 2 Results of lineal models testing the effects of sampling pretreatment (microwave, freeze, stove), species (according to Table 1), tissue (foliar, branch sapwood), and their interactions, on the concentrations of total nonstructural carbohydrates (NSC), starch, and low-molecular weight sugars (SS). Starch concentrations were $\log _{10}(y+1)$ transformed before analyses, where $y$ represents the concentration

\begin{tabular}{lrrrr}
\hline & df & F $(P$ value $)$ & \\
\cline { 3 - 5 } & & NSC & Starch & \multicolumn{1}{c}{ SS } \\
\hline Preservation treatment & 2 & $3.14(0.046)$ & $0.06(0.939)$ & $11.56(<0.001)$ \\
Species & 5 & $107.14(<0.001)$ & $59.21(<0.001)$ & $142.54(<0.001)$ \\
Tissue & 1 & $94.47(<0.001)$ & $13.04(<0.001)$ & $94.54(<0.001)$ \\
Preservation Treat*Species & 10 & $2.24(0.017)$ & $3.57(<0.001)$ & $3.59(<0.001)$ \\
Preservation Treat*Tissue & 2 & $12.31(<0.001)$ & $2.77(0.066)$ & $12.25(<0.001)$ \\
Species*Tissue & 5 & $50.03(<0.001)$ & $76.81(<0.001)$ & $93.12(<0.001)$ \\
Preservation Treat*Species*Tissue & 10 & $0.77(0.064)$ & $3.64(<0.001)$ & $5.57(<0.001)$ \\
& & & &
\end{tabular}

Total degrees of freedom were 179. Values in italics indicate statistical significance starch, and sugar concentration allocated to leaves and branches (i.e., significant interaction Species * Tissue, Table 2); NSC concentrations were similar between tissues in Ribes and higher in branch sapwood than leaves in Berberis, while sugar concentrations were significantly higher in branches than leaves in Berberis and Embothrium (Fig. 1).
Also, starch was not always higher in leaves than in branch sapwood (e.g., Berberis and Ribes, Fig. 1).

Across species and tissues, freezing produced significantly higher NSC and sugar concentrations than the other two treatments, for which concentrations resulted statistically similar (Fig. 2). Nonetheless, this result was driven by leaf
Fig. 1 Non-structural carbohydrate (NSC), starch, and low-molecular weight sugars (SS) concentrations in branch sapwood and leaves of six woody species (Table 1). Different uppercase letters indicate statistically significant differences among species; asterisk indicate differences between organs for a given species

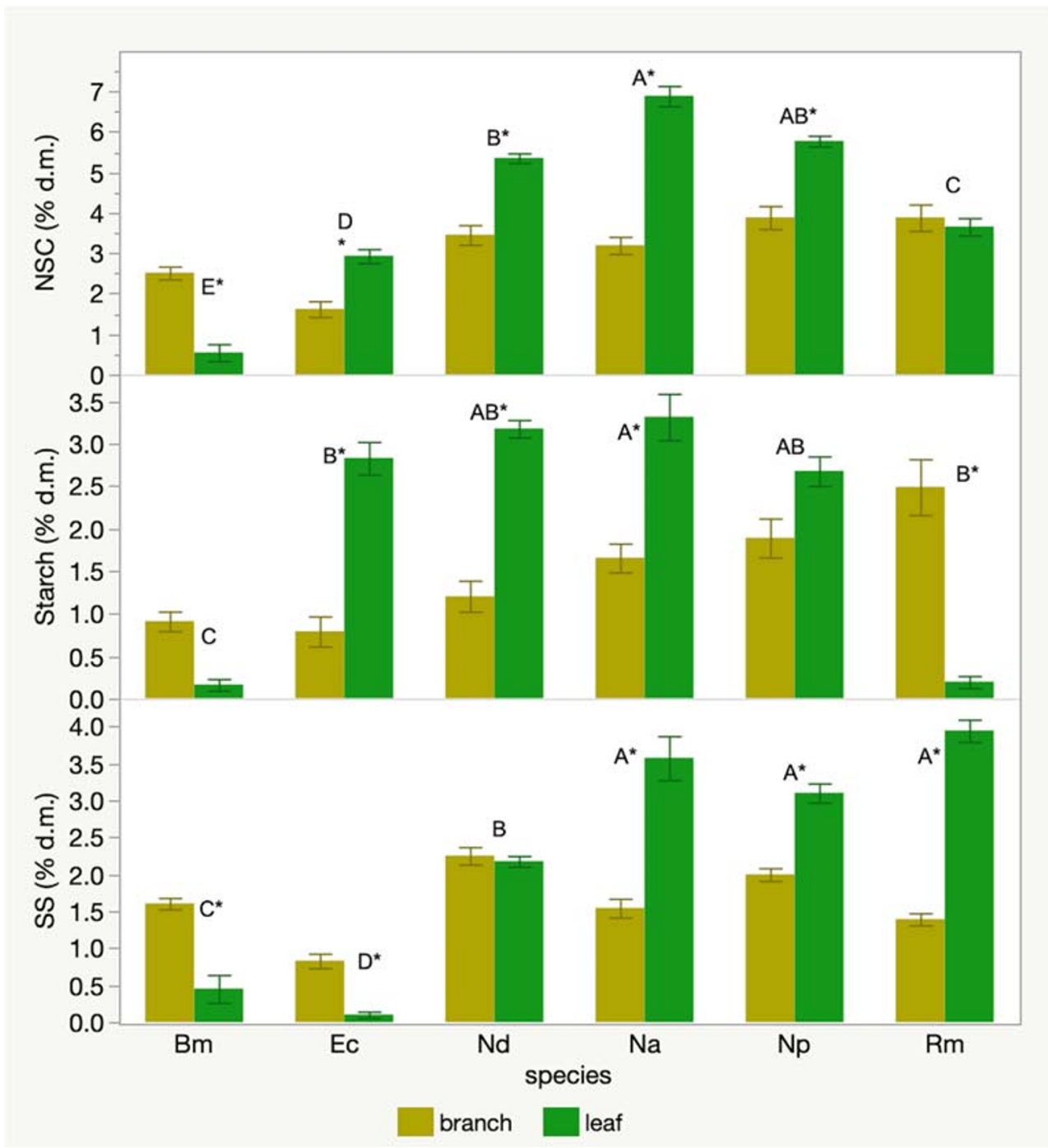


concentrations, as the three treatments resulted in similar branch sapwood NSC and sugar concentrations (i.e., significant interaction Tissue*Preservation Treatment, Table 2; Fig. 2). Regardless of the tissue, starch concentrations were unaffected by the sample preservation treatment (Table 1, Fig. 2).

Sample treatments had different effects on the NSC concentrations among species, regardless of the tissue (i.e., significant interaction Species * Preservation treatment and nonsignificant interaction Species * Preservation treatment * Tissue, Table 2). Thus, depending on the sample preservation treatment, some interspecific differences were statistically significant or not. For example, $N$. antarctica and Ribes had similar NSC concentrations when their tissues were microwaved or frozen before drying. However, the same two species had concentrations significantly different when they were placed directly in the stove, as Ribes (but not $N$. antarctica) had lower NSC concentrations relative to the other two treatments (Fig. 3).

Treatments also had different effects on the starch and sugar concentrations among species, although in these cases the tissue mattered (i.e., significant interaction species * treatment * tissue, Table 2). Freezing led to significantly lower leaf starch concentrations in $N$. antarctica, while microwaving led to significantly higher branch starch concentrations in Ribes (i.e., significant interaction species*tissue*treatment Table 2, Fig. 4). Treatments led to similar branch sugar

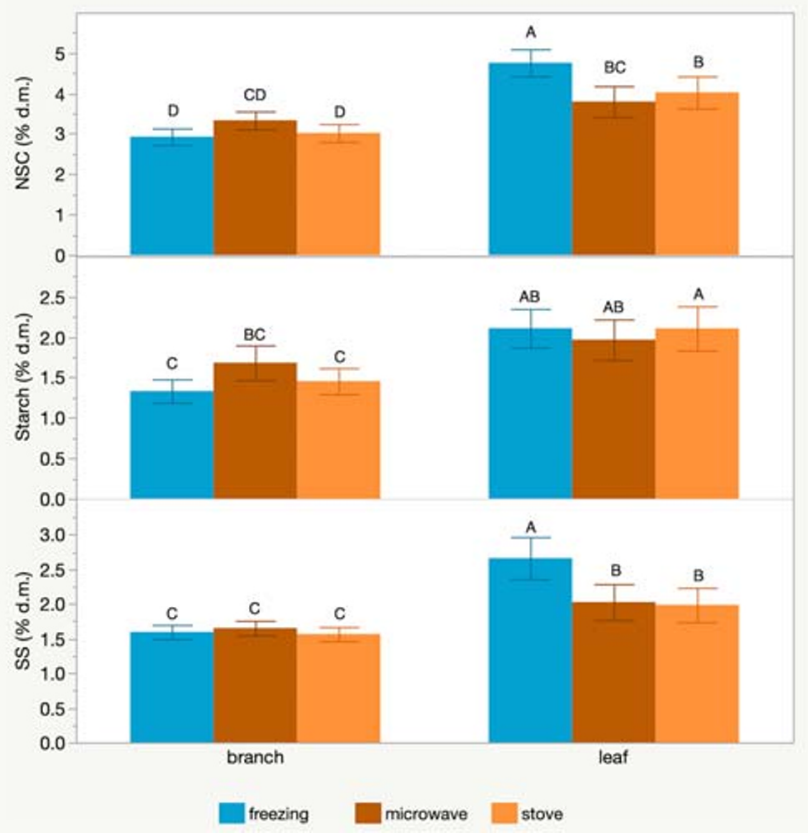

Fig. 2 Effect of sampling preservation treatments on non-structural carbohydrate (NSC), starch, and low-molecular weight sugars (SS) concentrations in branch sapwood and leaves (averaged for six woody species) (Table 1). Different uppercase letters indicate statistically significant differences among sample preservation treatments and tissues concentrations within species, but to significantly higher leaf sugar concentrations in Berberis and N. antarctica (Fig. 4).

\section{Discussion}

Across tissues and species, we unexpectedly found that sample preservation treatment using the microwave did not lead to significant differences in NSC concentrations compared with direct stove-drying at $70{ }^{\circ} \mathrm{C}$. This result suggests that sample microwaving was not efficient at halting the NSC losses associated with respiration and starch degradation during sample handling and processing. Lack of microwaving effects contrasts with previous studies that found microwaving an efficient sample preservation method compared with direct drying (Popp et al. 1996; Pelletier et al. 2010; Landhäusser et al. 2018). Nonetheless, Quentin et al. (2015) found that microwaving samples of Pinus edulis at $800 \mathrm{~W}$ required $180 \mathrm{~s}$ to deactivate enzymes, and that no microwaving or 90 s of microwaving was not effective at halting the enzymatic hydrolysis of starch and sucrose. This suggests that the duration of the microwaving in our study could have been insufficient to cause the expected differences. On the other hand, Landhäusser et al. (2018) found that $90 \mathrm{~s}$ microwaving at $600 \mathrm{~W}$ led to significantly higher NSC, starch, and sugar concentrations than no microwaving (direct stovedrying) in aspen leaves and stems, with the greatest difference of $13.5 \%$ for sugars between microwaved and nonmicrowaved aspen leaves. The same study, however, found no significant effect for either NSC, starch, or sugar concentrations of spruce needles, revealing that the efficacy of a handling method of samples before drying depends on the type of tissue and perhaps on the functional group. Consistent with the findings of Landhäusser et al. (2018), here we found that microwaving effects were highly tissue- and species-specific, resulting in starch concentrations significantly higher than in the other treatments for branch sapwood of Ribes only (Fig. 4).

Leaf NSC and sugar concentrations were significantly higher when samples were frozen before stove-drying, than when samples were microwaved or did not receive any pretreatment. This result suggests that freezing was the best method to handle leaf samples but made no difference from the other methods to handle branch sapwood (Fig. 2). This result indicates that, contrary to what we had expected, leakage losses were not meaningful or at least not more important than losses in the other methods (e.g., caused by respiration). The reduced leakage could relate to the capacity to tolerate the effects of extracellular (apoplastic) ice formation, such as dehydration or cell shrinkage (Sakai and Larcher 1987). Such capacity requires tissues to maintain their membrane stability in spite of ice formation (i.e., freezing tolerance). Freezing tolerance is the most common mechanism of freezing 
Fig. 3 Non-structural carbohydrate (NSC), starch, and low-molecular weight sugars (SS) concentrations in six woody species (Table 1). Values were calculated across branch sapwood and leaves. Different uppercase letters indicate statistically significant differences among sampling preservation treatments and species. Starch concentrations were $\log _{10}(y+1)$ transformed before analyses, where $y$ represents the concentration

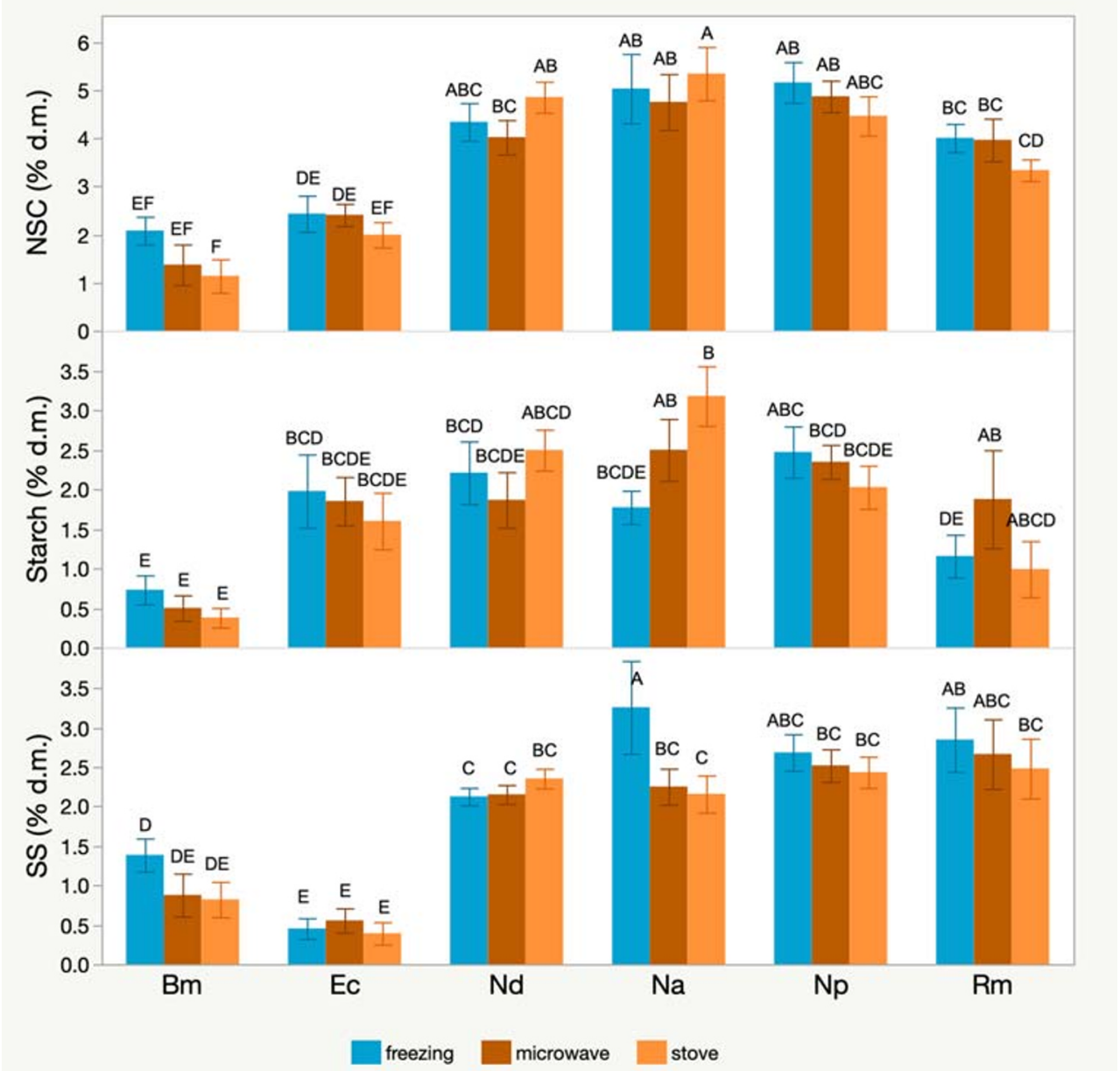

resistance in plant species of the southern Andes (e.g., alpine plants, temperate trees) (Bannister and Lord 2006; SierraAlmeida et al. 2009), and it has been reported in two of the species studied here: Nothofagus dombeyi (Reyes-Diaz et al. 2005) and Embothrium coccineum (Alberdi 1995). In the same line, temperature as low as $-20{ }^{\circ} \mathrm{C}$ is tolerated by Berberis empetrifolia (Bannister and Lord 2006), a shrub similar in shape and distribution to B. microphylla. Likewise, freezing resistance of temperatures lower than $-15^{\circ} \mathrm{C}$ are common in Nothofagus species (Alberdi et al. 1985). The capacity to keep membrane integrity in the face of ice could also account for the significantly higher leaf sugar concentrations in Berberis and $N$. antarctica with freezing, although this could also be indicative of increased starch hydrolysis by freezing. Interestingly, in $N$. antarctica, starch hydrolysis in leaves appeared to occur mostly with freezing and this reaction was not accompanied by similar sugar respiration losses but rather by a sugar accumulation (Fig. 4). A potential explanation for this result may rest on the higher freezing resistance of $N$. antarctica compared with the other species. Buds of Nothofagus antarctica have been found to resist up to $22{ }^{\circ} \mathrm{C}$ in winter, while this value was $-18^{\circ} \mathrm{C}$ for $N$. pumilio, and varied from -1 to $-13{ }^{\circ} \mathrm{C}$ in the leaves of the evergreen Nothofagus (Alberdi et al. 1985). In general, freezing resistance in Nothofagus species relies largely on the accumulation of compatible solutes comprised mainly by sugars (Alberdi et al. 1985; Reyes-Diaz et al. 2005). Thus, it is possible that the leaf starch hydrolysis and concomitant leaf sugar accumulation found by this study in response to freezing reflects a fast acclimation response of this species to freezing conditions.

Differences in sample pretreatments found by this study were highly species- and tissue-specific but were not necessarily related to the metabolic rates as we had expected. For example, although Ribes had the highest $\mathrm{N}$ and P concentrations in both the branch sapwood and the leaves, microwave treatment appeared to have reduced starch hydrolysis only in its branch sapwood. Factors other than the species- and tissuespecific metabolic rates probably affected the carbohydrate concentrations in the different pretreatments. It has been found that starch solubility in hot water depends on the starch molecular structure, which may be altered by microwaving and freezing-thawing (Tao et al. 2015; Fan et al. 2017). Thus, 
Fig. 4 Low-molecular weight sugars (SS) and starch concentrations in branch sapwood and leaves of six woody species (Table 1). Asterisk indicates differences statistically significant between freezing or microwave and the other two sample preservation treatments within a same species

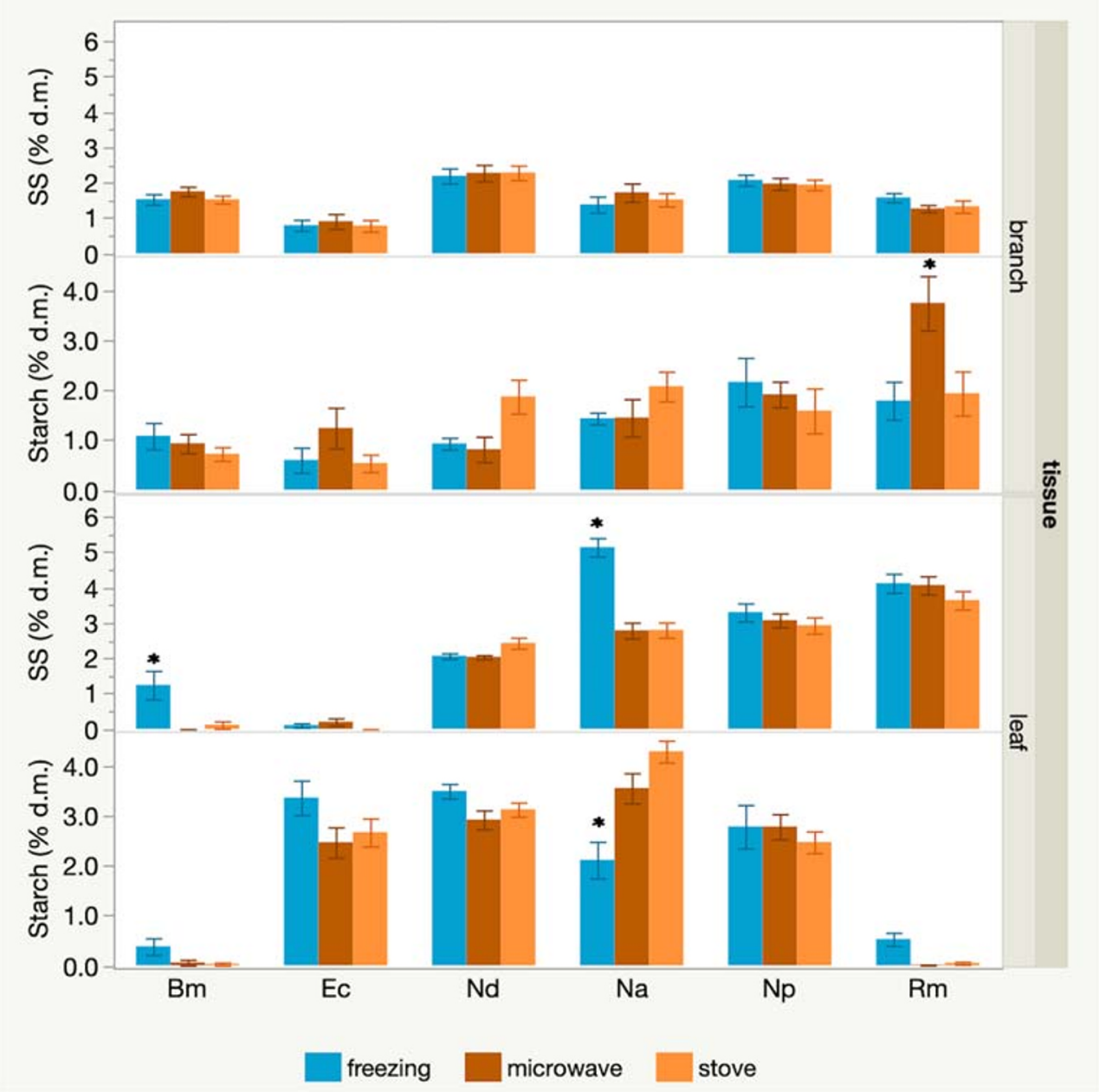

microwaving or freezing could have reduced the starch hydrolysis in some samples, but they could also have reduced the starch solubility in hot water. In fact, we used hot water to extract sugars and starch, which has been found to be less effective than ethanol extraction, particularly when the NSC quantification is enzymatic (as in this study). Alternative methods of starch extraction (e.g., hot ethanol) could be useful to distinguish potential effects of the pretreatments on the starch solubility from those on starch hydrolysis.

\section{Conclusion}

Our results confirm that carbohydrate losses during sample handling vary among species and tissues, but they also show that such differences are likely unrelated to metabolic rates. We found differences that were unrelated to SLA, WD, and tissue nutrient concentrations (Table 1). We suggest that the membrane stability to extreme temperatures could better explain the differences found by this study, particularly the higher sugar and NSC concentration in samples that were frozen before drying. Nonetheless, we emphasize that such differences were in general small, in agreement with recent studies which found that sample handling and storage are unlikely to be a major source of variation in NSC concentrations (Pinkard 2018).

Acknowledgments Authors thank Juan Pablo Mora for assistance in the sample processing.

Funding information This study was funded by Fondecyt (Grants 1160330 and 1190927).

Data availability The datasets generated during and analyzed during the current study are publicly available in the Dryad repository (Piper and Reyes 2020) (https://doi.org/10.5061/dryad.4b8gtht87).

Compliance with ethical standards The authors declare that they obtained the appropriate permissions from responsible authorities for conducting the study in Coyhaique National Reserve.

Conflict of interest The authors declare that they have no conflicts of interest. 


\section{References}

Adams HD, Zeppel MJB, Anderegg WRL, Hartmann H, Landhäusser SM, Tissue DT, Huxman TE, Hudson PJ, Franz TE, Allen CD, Anderegg LDL, Barron-Gafford GA, Beerling DJ, Breshears DD, Brodribb TJ, Bugmann H, Cobb RC, Collins AD, Dickman LT, Duan H, Ewers BE, Galiano L, Galvez DA, Garcia-Forner N, Gaylord ML, Germino MJ, Gessler A, Hacke UG, Hakamada R, Hector A, Jenkins MW, Kane JM, Kolb TE, Law DJ, Lewis JD, Limousin J-M, Love DM, Macalady AK, Martínez-Vilalta J, Mencuccini M, Mitchell PJ, Muss JD, O’Brien MJ, O’Grady AP, Pangle RE, Pinkard EA, Piper FI, Plaut JA, Pockman WT, Quirk J, Reinhardt K, Ripullone F, Ryan MG, Sala A, Sevanto S, Sperry JS, Vargas R, Vennetier M, Way DA, Xu C, Yepez EA, McDowell NG (2017) A multi-species synthesis of physiological mechanisms in drought-induced tree mortality. Nat Ecol Evol 1:1285-1291. https://doi.org/10.1038/s41559-017-0248-x

Alberdi M (1995) Ecofisiología de especies leñosas de los bosques hidrófilos templados de Chile: resistencia a la sequía y bajas temperaturas. In: Kalin Arroyo M, Armesto JJ, Villagrán C (eds) Ecología de los Bosques Nativos de Chile. Editorial Universitaria, Santiago, pp 279-299

Alberdi M, Romero M, Rios D, Wenzel H (1985) Altitudinal gradients of seasonal frost resistance in Nothofagus communities of southern Chile. Acta Oecologica/Oecologia 6:21-30

Bannister P, Lord JM (2006) Comparative winter frost resistance of plant species from southern Africa, Australia, New Zealand, and South America grown in a common environment (Dunedin, New Zealand). N Z J Bot 44:109-119. https://doi.org/10.1080/ 0028825X.2006.9513011

Butler DR, Landsberg JJ (1981) Respiration rates of apple trees, estimated by $\mathrm{CO}_{2}$-efflux measurements. Plant Cell Environ 4:153-159. https://doi.org/10.1111/j.1365-3040.1981.tb01037.x

Canadell J, López-Soria L (1998) Lignotuber reserves support regrowth following clipping of two Mediterranean shrubs. Funct Ecol 12:3138. https://doi.org/10.1046/j.1365-2435.1998.00154.x

Chapin FS, Schulze ED, Mooney HA (1990) The ecology and economics of storage in plants. Annu Rev Ecol Syst 21:423-447. https://doi. org/10.1146/annurev.es.21.110190.002231

Fan D, Wang L, Zhang N, Xiong L, Huang L, Zhao J, Wang M, Zhang H (2017) Full-time response of starch subjected to microwave heating. Sci Rep 7:3967. https://doi.org/10.1038/s41598-017-04331-2

Galiano L, Martinez-Vilalta J, Lloret F (2011) Carbon reserves and canopy defoliation determine the recovery of Scots pine $4 \mathrm{yr}$ after a drought episode. New Phytol 190:750-759. https://doi.org/10. $1111 / \mathrm{j} .1469-8137.2010 .03628 . x$

Hendrix DL, Peelen KK (1987) Artifacts in the analysis of plant tissues for soluble carbohydrates. Crop Sci 27:710-715. https://doi.org/10. 2135/cropsci1987.0011183X002700040022x

Hendrix DL, Mauney JR, Kimball BA, Lewin K, Nagy J, Hendrey GR (1994) Influence of elevated $\mathrm{CO}_{2}$ and mild water stress on nonstructural carbohydrates in field-grown cotton tissues. Agric For Meteorol 70:153-162. https://doi.org/10.1016/0168-1923(94) 90054-X

Hoch G, Popp M, Körner C (2002) Altitudinal increase of mobile carbon pools in Pinus cembra suggests sink limitation of growth at the Swiss treeline. Oikos 98:361-374. https://doi.org/10.1034/j.16000706.2002.980301.x

Klein T, Hoch G, Yakir D, Körner C (2014) Drought stress, growth and nonstructural carbohydrate dynamics of pine trees in a semi-arid forest. Tree Physiol 34:981-992. https://doi.org/10.1093/treephys/ tpu071

Labate CA, Leegood RC (1989) Influence of low temperature on respiration and contents of phosphorylated intermediates in darkened barley leaves. Plant Physiol 91:905-910. https://doi.org/10.1104/ pp.91.3.905

Landhäusser SM, Chow PS, Dickman LT, Furze ME, Kuhlman I, Schmid S, Wiesenbauer J, Wild B, Gleixner G, Hartmann H, Hoch G, McDowell NG, Richardson AD, Richter A, Adams HD (2018) Standardized protocols and procedures can precisely and accurately quantify non-structural carbohydrates. Tree Physiol 38:1764-1778. https://doi.org/10.1093/treephys/tpy118

Martínez-Vilalta J, Sala A, Asensio D, Galiano L, Hoch G, Palacio S, Piper FI, Lloret F (2016) Dynamics of non-structural carbohydrates in terrestrial plants: a global synthesis. Ecol Monogr 86:495-516. https://doi.org/10.1002/ecm.1231

Pelletier S, Tremblay GF, Bertrand A, Bélanger G, Castonguay Y, Michaud R (2010) Drying procedures affect non-structural carbohydrates and other nutritive value attributes in forage samples. Anim Feed Sci Technol 157:139-150. https://doi.org/10.1016/j.anifeedsci. 2010.02.010

Piispanen R, Saranpää P (2001) Variation of non-structural carbohydrates in silver birch (Betula pendula Roth) wood. Trees 15:444-451. https://doi.org/10.1007/s004680100125

Pinkard EA (2018) Doing the best we can: the realities of measuring nonstructural carbohydrates in trees. Tree Physiol 38:1761-1763. https://doi.org/10.1093/treephys/tpy138

Piper FI, Fajardo A (2014) Foliar habit, tolerance to defoliation and their link to carbon and nitrogen storage. J Ecol 102:1101-1111. https:// doi.org/10.1111/1365-2745.12284

Piper FI, Fajardo A (2016) Carbon dynamics of Acer pseudoplatanus seedlings under drought and complete darkness. Tree Physiol 36: 1400-1408. https://doi.org/10.1093/treephys/tpw063

Piper FI, Reyes A (2020) Does microwaving or freezing reduce the losses of non-structural carbohydrates during plant sample processing? Version 2. Dryad Repository [Dataset]. https://doi.org/10.5061/ dryad.4b8gtht 87

Piper FI, Sepúlveda P, Bustos-Salazar A, Zúñiga-Feest A (2017) Carbon allocation to growth and storage in two evergreen species of contrasting successional status. Am J Bot 104:654-662. https://doi.org/ 10.3732/ajb. 1700057

Plavcova L, Hoch G, Morris H, Ghiasi S, Jansen S (2016) The amount of parenchyma and living fibers affects storage of nonstructural carbohydrates in young stems and roots of temperate trees. Am J Bot 103: 603-612. https://doi.org/10.3732/ajb.1500489

Popp M, Lied W, Meyer AJ, Richter A, Schiller P, Schwitte H (1996) Sample preservation for determination of organic compounds: microwave versus freeze-drying. J Exp Bot 47:1469-1473. https://doi. org $/ 10.1093 / \mathrm{jxb} / 47.10 .1469$

Quentin AG, Pinkard EA, Ryan MG, Tissue DT, Baggett LS, Adams HD, Maillard P, Marchand J, Landhäusser SM, Lacointe A, Gibon Y, Anderegg WRL, Asao S, Atkin OK, Bonhomme M, Claye C, Chow PS, Clément-Vidal A, Davies NW, Dickman LT, Dumbur R, Ellsworth DS, Falk K, Galiano L, Grünzweig JM, Hartmann H, Hoch G, Hood S, Jones JE, Koike T, Kuhlmann I, Lloret F, Maestro M, Mansfield SD, Martínez-Vilalta J, Maucourt M, McDowell NG, Moing A, Muller B, Nebauer SG, Niinemets Ü, Palacio S, Piper F, Raveh E, Richter A, Rolland G, Rosas T, Saint Joanis B, Sala A, Smith RA, Sterck F, Stinziano JR, Tobias M, Unda F, Watanabe M, Way DA, Weerasinghe LK, Wild B, Wiley E, Woodruff DR (2015) Non-structural carbohydrates in woody plants compared among laboratories. Tree Physiol 35:1146-1165. https://doi.org/10.1093/ treephys/tpv073

Reyes-Diaz M, Alberdi M, Piper FI, Bravo LA, Corcuera LJ (2005) Low temperature responses of Nothofagus dombeyi and Nothofagus nitida, two evergreen species from south Central Chile. Tree Physiol 25:1389-1398

Sakai A, Larcher W (1987) Frost survival of plants. Springer-Verlag, Berlin 
Sierra-Almeida A, Cavieres LA, Bravo LA (2009) Freezing resistance varies within the growing season and with elevation in highAndean species of Central Chile. New Phytol 182:461-469. https://doi.org/10.1111/j.1469-8137.2008.02756.x

Smith D (1973) Influence of drying and storage conditions on nonstructural carbohydrate analysis of herbage tissue - a review. Grass Forage Sci 28:129-134. https://doi.org/10.1111/j.1365-2494.1973. tb00733.x

Steffen KL, Arora R, Palta JP (1989) Relative sensitivity of photosynthesis and respiration to freeze-thaw stress in herbaceous species. Import Realistic Freeze-Thaw Protocols 89:1372-1379. https://doi. org/10.1104/pp.89.4.1372

Tao H, Yan J, Zhao J, Tian Y, Jin Z, Xu X (2015) Effect of multiple freezing/thawing cycles on the structural and functional properties of waxy rice starch. PLoS One 10:e127138-e0127138. https://doi. org/10.1371/journal.pone. 0127138

Wiley E, Rogers BJ, Hodgkinson R, Landhäusser SM (2016) Nonstructural carbohydrate dynamics of lodgepole pine dying from mountain pine beetle attack. New Phytol 209:550-562. https://doi. org/10.1111/nph.13603

Wyka TP, Karolewski P, Zytkowiak R, Chmielarz P, Oleksyn J (2016) Whole-plant allocation to storage and defense in juveniles of related evergreen and deciduous shrub species. Tree Physiol 36:536-547. https://doi.org/10.1093/treephys/tpv108

Publisher's note Springer Nature remains neutral with regard to jurisdictional claims in published maps and institutional affiliations. 